\title{
Ca-P spots modified zirconia by liquid precursor infiltration and the effect on osteoblast-like cell responses
}

\author{
Yongmei $\mathrm{LI}^{1 *}$, Yan LIU ${ }^{1,2 *}$, Zutai ZHANG ${ }^{1}$, Ruishen ZHUGE ${ }^{1}$, Ning DING ${ }^{1}$ and Yueming TIAN ${ }^{1}$ \\ ${ }^{1}$ School of Stomatology, Capital Medical University, Beijing 100050, China \\ ${ }^{2}$ Changle People's Hospital, Shandong Province, China \\ Corresponding author, Zutai ZHANG; E-mail: showazhang@hotmail.com
}

\begin{abstract}
Ca-P spots modified zirconia by liquid precursor infiltration and the cell responses were investigated. Pre-sintered zirconia specimens were immersed in Ca-P precursor solution. After dense sintering, scanning electron microscopy showed Ca-P spots were formed on the zirconia and anchored with zirconia substrates. The distribution density was increased with the extension of immersion time. Energy dispersive spectrometer confirmed the stoichiometric $\mathrm{Ca} / \mathrm{P}$ ratio was about 1.67. After hydrothermal treatment, Ca-P spots turned into rod crystals where diffraction peaks of tricalcium phosphate and hydroxyapatite were detected by X-ray diffraction, and $\mathrm{Ca}^{2+}$ and $\mathrm{PO}_{4}{ }^{3-}$ release decreased slightly $(p>0.05)$. There was no significant decrease on three-point bending strength $(p>0.05)$. Osteoblast-like MC3T3-E1 cells attached and spread well and showed higher proliferation on Ca-P spots modified zirconia ( $p<0.05)$, though its initial alkaline phosphatase activity was not significant high $(p>0.05)$. In conclusion, Ca-P liquid precursor infiltration is a potential method to modify the zirconia ceramics for improving bioactivity.
\end{abstract}

Keywords: Zirconia, Ca-P spots, Liquid precursor infiltration, Surface modification, Osteoblast-like cells

\section{INTRODUCTION}

Since Brånemark et $a l .{ }^{1}{ }^{1}$ discovered titanium and bone could be completely integrated, titanium implants have been established as a reliable treatment option for the replacement of missing teeth over forty years ${ }^{2}$. In spite of well-documented biocompatibility and suitability for tooling, it has been reported that titanium can cause unwanted chemical-biological interactions like tissue discoloration $^{3)}$ and allergic reactions ${ }^{4}$. Additionally, a drawback from an aesthetic point of view is the gray color of titanium ${ }^{5}$, which may pose a problem in cases with visible titanium and thin soft tissues including the metallic implant shoulder shining through the gingival or even being exposed as a consequence of peri-implant tissue $\operatorname{loss}^{6}$. In addition, several studies have reported titanium alloys may affect nuclear magnetic resonance $(\mathrm{MRI})^{7)}$.

Zirconia ceramics possess excellent mechanical strength, biocompatibility, chemical and dimensional stability $^{8}$. As non-metallic materials, it has esthetic advantages. Moreover, seldom cases of allergic reactions and MRI problems caused by zirconia ceramics have been reported. Besides, not only was zirconia used as a biomaterial find application in hip joint replacement ${ }^{9}$, it has also been highly used as a metal replacement for crowns, prostheses, brackets and implants ${ }^{10,11)}$. However, as implants, zirconia shows morphological fixation with the surrounding tissues without producing any chemical or biological bonding ${ }^{12)}$. Its bioinertness could not induce the formation of new

\footnotetext{
*Authors who contributed equally to this work.

Color figures can be viewed in the online issue, which is available at J-STAGE.

Received Jul 20, 2017: Accepted Nov 2, 2017

doi:10.4012/dmj.2017-246 JOI JST.JSTAGE/dmj/2017-246
}

bone, furthermore resulting in fibrous film formation, the loose fixation and leading to implant failure.

There are many studies regarding zirconia surface modifications to enhance osseointegration, involving machining ${ }^{13)}$, sandblasting ${ }^{14,15)}$, laser treatment ${ }^{16)}$, plasma spraying ${ }^{17)}$, sol-gel ${ }^{18)}$ and surface bioactive coatings $^{19-21)}$. However, surface modification of zirconia ceramics is technically difficult ${ }^{22}$ due to its high hardness. Sandblasting might alter the phase transformation integrity of the material and cause micro cracks $^{8}$. Plasma spraying would change the component of the coatings. In addition, there is a weak bonding between the substrate and coating layer by plasma spraying ${ }^{17)}$, as well as sol-gel method ${ }^{18)}$. Recently, coating with cell adhesion peptides surface modification has been studied as a strategy to promote zirconia implant integration. Moreover, some researchers have focused on the development of coatings that release therapeutic biomolecules, such as BMP-2 ${ }^{21)}$.

Excellent osseointegration is the final goal of bone tissue healing around implant materials. Studies suggested that the biocompatibility of the inorganic biomaterials surface can be significantly improved by the implementation of a biomimetic process which mimics the formation of bone tissues. Calcium and phosphorus are the main inorganic components of human bones and teeth. Calcium phosphate are osteoconductive and directly bond to bone ${ }^{23)}$, and have been considered precursors to bone apatite formation in $v_{i v 0^{24}}$. Therefore, there are many methods reported for preparation of Ca-P composite coatings on implant substrates to improve its osseointegration.

Liquid precursor infiltration is capable of 
incorporating a desired content of exotic elements with controllable distribution ${ }^{25)}$. Whereas, until now, the biocompatibility of $\mathrm{Ca}-\mathrm{P}$ modified zirconia by liquid precursor infiltration method has rarely been addressed. The aim of the present study was to investigate effectiveness of Ca-P modified zirconia by liquid precursor infiltration method and explore the effect of cellular responses to Ca-P modified zirconia.

\section{MATERIALS AND METHODS}

The flow chart of experiment was shown in Fig. 1.

\section{Fabrication of zirconia specimens}

Zirconia discs $\left(\mathrm{N}_{1}=292,16 \mathrm{~mm}\right.$ in diameter, $1.6 \mathrm{~mm}$ in thickness) were cut from pre-sintered zirconia ceramic blocks (High transparent material, Nissin-Metec China, Jiangsu, China) with a diamond saw (Isomet 4000 Linear Precision Saw, Buehler, Lake Bluff, IL, USA) under coolant irrigation. Zirconia beams $\left(\mathrm{N}_{2}=40\right)$ with dimensions of $25 \times 5 \times 1.5 \mathrm{~mm}$ were prepared for threepoint bending test (ISO 6872) as well. All specimens were polished with a polishing machine (YMP-2, Shanghai Jinxiang Machinery Equipment, Shanghai, China) using a series of silicon carbide ( $\mathrm{SiC}$ ) abrasive papers in sequence (grit 800, 1000 and 1200; Struers, Ballerup, Denmark) for $15 \mathrm{~s}$ under water irrigation at 300 rotations per min to obtain the same flat surfaces. After ultrasonically cleaned for $10 \mathrm{~min}$ in ethanol and deionized water, all specimens subsequently dried and were put into an oven (Vita Zahnfabrik, Bad Sackingen, Germany) at $400^{\circ} \mathrm{C}$ for $2 \mathrm{~h}$.

\section{Preparation of Ca-P precursor solution}

Ca-P precursor solution $(\mathrm{Ca} / \mathrm{P}$ mole ratio was 1.7$)$ was obtained by mixing $1.88 \mathrm{~mol} / \mathrm{L} \mathrm{CaCl}_{2}$ solution to 0.93 $\mathrm{mol} / \mathrm{L} \mathrm{NaH}_{2} \mathrm{PO}_{4}$ solution with the same volume. Then,
$\mathrm{pH}$ value of Ca-P precursor solution was adjusted to 2.0 with $1 \mathrm{~mol} / \mathrm{L}$ hydrochloric acid $(\mathrm{HCl})$ solution by $\mathrm{pH}$ meter (868 model, Orion Research, MA, USA).

\section{Preparation of Ca-P modified zirconia}

Zirconia specimens were randomly divided into four groups (Fig. 1): Control group $\mathrm{C}\left(\mathrm{n}_{1}=107, \mathrm{n}_{2}=10\right)$ with no treatments; experimental group E1 $\left(\mathrm{n}_{1}=9, \mathrm{n}_{2}=10\right)$, E2 $\left(\mathrm{n}_{1}=167, \mathrm{n}_{2}=10\right)$ and E3 $\left(\mathrm{n}_{1}=9, \mathrm{n}_{2}=10\right)$ : group E1 was immersed in Ca-P precursor solution for $1 \mathrm{~min}$; group E2 was immersed in Ca-P precursor solution for $1 \mathrm{~min}$, then take it out and keep it at room temperature for 5 min, finally immersed for 1 min again; group E3 was immersed in Ca-P precursor solution for another $1 \mathrm{~min}$ on the base of group E2. After $12 \mathrm{~h}$ at room temperature, the specimens were dense sintered in furnace ( $\mathrm{KaVo}$ Everest thermo, Baden Wurttemberg, Germany) according to the manufacturer's instructions at a heating speed of $5^{\circ} \mathrm{C} / \mathrm{min}$ to $1,450^{\circ} \mathrm{C}$, holding for $2 \mathrm{~h}$, subsequently naturally cooling to room temperature.

\section{The characteristic of Ca-P modified zirconia}

After dense sintering, surface morphologies of zirconia specimens were observed by scanning electron microscopy (SEM) (Phenom World, Eindhoven, The Netherlands) at $10 \mathrm{kV}$ operating in secondary electron mode, and elemental compositions of the groups were analyzed with energy dispersive spectroscopy (EDS). The phases composition of group $\mathrm{C}$ and E2 were investigated by X-ray diffraction (XRD) (SEIFERT, Ahrensburg, Germany) equipped with Cross Beam Optics (CBO) and $\mathrm{Cu} \mathrm{K} \alpha$ radiation $(\lambda=0.154157 \mathrm{~nm})$. The diffractometer was operated at $40 \mathrm{kV}$ with the corresponding current of $35 \mathrm{~mA}$. Each run was performed with 2 theta $(2 \theta)$ values between $20^{\circ}$ and $70^{\circ}$ carried out in parallel beam mode with a fixed incident angle of $0.5^{\circ}$. One specimen randomly selected from group $\mathrm{E} 2$ was sectioned to

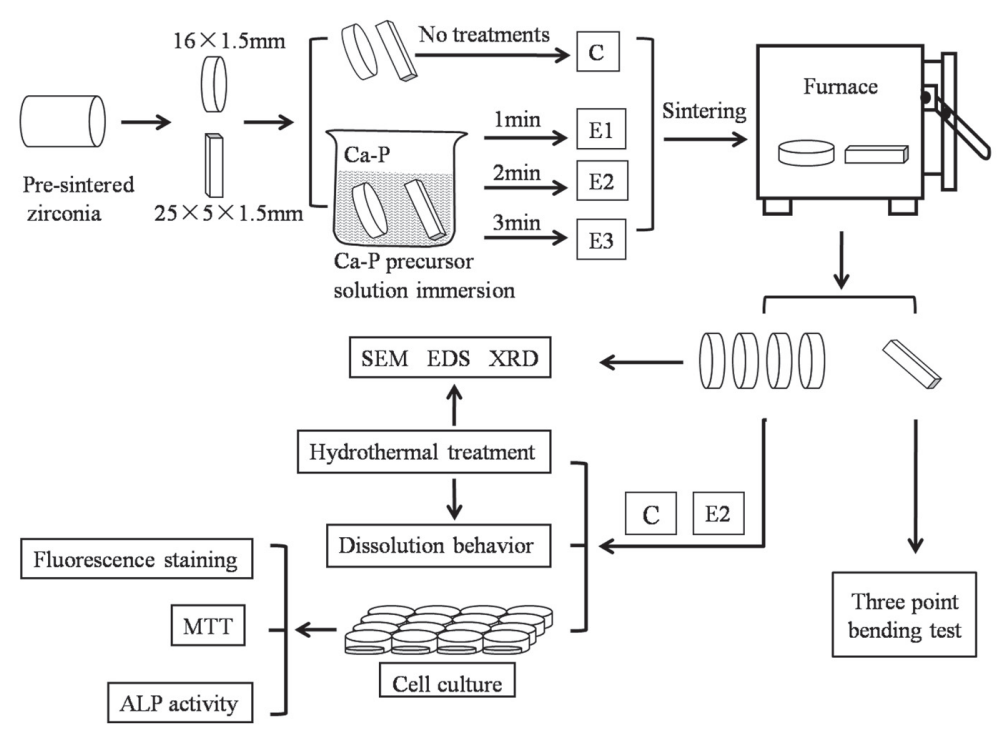

Fig. 1 The flow chart of the experiment. 
observe the Ca-P infiltration.

\section{Hydrothermal treatment and the characteristic}

To explore whether the amorphous calcium phosphorus on zirconia is the precursor of hydroxyapatite (HAP), after sintering, zirconia specimens of group E2 $\left(\mathrm{n}_{1}=59\right)$ were placed at $135^{\circ} \mathrm{C}, 0.4 \mathrm{MPa}$ for $8 \mathrm{~h}$ (autoclave sterilizer, MLS-3750, Sanyo, Osaka, Japan). The surface characteristic was analyzed by SEM, EDS and XRD.

\section{Dissolution behavior}

To test the dissolution behavior of the Ca-P spots on zirconia, specimens of group C, group E2 before and after hydrothermal treatment were placed into sterile polystyrene culturing dishes (24-well multidish, Nunc, Wiesbaden, Germany), and each specimen was immersed in $1 \mathrm{~mL}$ deionized water. The samples were placed in an incubator at $37^{\circ} \mathrm{C}$ with an integrated shaker (160 rpm, Unimax 1010, Heidolph, Klein, Germany). At the day of $1,2,3,4,7,14$ and 30 , the release of calcium ion $\left(\mathrm{Ca}^{2+}\right)$ and phosphate ion $\left(\mathrm{PO}_{4}{ }^{3-}\right)$ were tested by automatic chemistry analyzer (LABOSPECT TS, Hitachi High Technologies, Tokyo, Japan) in accordance to manufacturer's instruction, respectively.

\section{Three-point bending strength}

The three-point bending strength $(\sigma)$ of zirconia beams was tested by a universal testing machine (AG-X Plus, Shimadzu, Kyoto, Japan) at a constant speed of $0.5 \mathrm{~mm} /$ min, and the value was calculated according to the ISO 6872 standard:

$$
\sigma=3 F l / 2 w b^{2}
$$

Where $F=$ load $(\mathrm{N}) ; l=$ test $\operatorname{span}(\mathrm{mm}) ; w=$ width of specimen (mm); and $b=$ thickness of specimen $(\mathrm{mm})$.

\section{Osteoblastic cell culture}

In order to explore the effects of Ca-P modified zirconia on the cell responses, MC3T3-E1 mouse pre-osteoblasts (CRL-2593, American Type Culture Collection [ATCC], Manassas, VA, USA) were cultured on the group C and representative experimental group E2. Before the cell culture experiments, all samples were sterilized in $70 \%$ ethanol for $15 \mathrm{~min}$ and then dried at $121^{\circ} \mathrm{C}$ for 30 min (MLS-3750, Sanyo). MC3T3-E1 cells were cultured in alpha minimal essential medium ( $\alpha$-MEM) (Gibco, Thermo Fisher Scientific, Waltham, MA, USA) with $10 \%$ fetal bovine serum (FBS, Gibco Laboratories Life Technologies, NY, USA) in a humidified atmosphere of $5 \% \quad \mathrm{CO}_{2}$ at $37^{\circ} \mathrm{C}$. After subculturing, the cells were washed with phosphate-buffered saline (PBS, Sinopharm Chemical Reagent, Shanghai, China), detached with trypsin solution (0.25\% trypsin, Hyclone, UT, USA) at $37^{\circ} \mathrm{C}$ for $10 \mathrm{~min}$, and centrifuged and resuspended for further reseeding and growth tests. The medium was changed every 2 days.

\section{Cell morphology}

The cells were seeded at a density of $1 \times 10^{4}$ cells $/ \mathrm{cm}^{2}$ in 24-well polystyrene plates with the modified surface of the zirconia discs facing upwards. At 24 and $72 \mathrm{~h}$ of incubation, $\operatorname{six}\left(\mathrm{n}_{1}=6\right.$ per group) wells of each group were stained with Phalloidin (5 ug/mL, Sigma, MO, USA) for actin filament and DAPI (5 ug/mL, Sigma) for nuclei, respectively. The specimens were examined by confocal laser scanning microscopy (CLSM, Olympus, Tokyo, Japan).

\section{Cell viability assays}

The cell viability ( $\mathrm{n}_{1}=24$ per group) was evaluated by MTT (3-[4, 5-dimethylthiazol-2-yl]-2, 5-diphenyltetrazolium bromide) method. The cells were seeded at a density of $3 \times 10^{4} \mathrm{cell} / \mathrm{cm}^{2}$ on each disc. At each culture period $(1,3$, 5 and 7 days), five microliters of MTT solution freshly prepared $(5 \mathrm{mg} / \mathrm{mL}$ MTT reagent in PBS) (Invitrogen, Carlsbad, CA, USA) and $200 \mu \mathrm{L}$ of medium were add to each well. After incubated at $37^{\circ} \mathrm{C}$ for $4 \mathrm{~h}$, MTT was drained from every well and afterwards they were placed into Dimethyl sulfoxide (DMSO, Invitrogen). Ultimately, the incubated suspension was then placed into a 96-well plate, and the absorbance was read at $490 \mathrm{~nm}$ using a microplate reader (Molecular Devices, Sunnyvale, CA, USA).

\section{Alkaline phosphatase (ALP) activity assay}

ALP activity ( $\mathrm{n}_{1}=9$ per group) was performed according to the protocol of the ALP activity assay kit (Nanjing Jiancheng Bioengineering Institute, Nanjing, China). Cells were seeded at a density of $3 \times 10^{4} \mathrm{cell} / \mathrm{cm}^{2}$ on each disc in 24-well plates. At culture days 3, 7 and 14, the total protein content was measured by using BCA protein assay reagent (Nanjing Jiancheng Bioengineering Institute). Its absorbance was subsequently measured at $410 \mathrm{~nm}$ using a spectrophotometer.

\section{Statistical analysis}

Statistical analysis of the data was performed by oneway analysis of variance (ANOVA) with Tukey's posthoc test. The statistical significance level was set at $\alpha=0.05$. $p$ Value of $<0.05$ were considered statistically significant.

\section{RESULTS}

\section{Characterization of Ca-P modified zirconia}

Figure 2 showed the representative SEM images of Ca-P modified zirconia. Compared with group C (Fig. 2a), there were substance showed clusters like distribution formed on the surfaces of group E1 (Fig. 2b), E2 (Fig. 2c) and E3 (Fig. 2d). It is relatively evenly distributed and the distribution density of spots was increased from groups E1 to E3.

The section SEM images of group E2 showed the spots infiltrated into zirconia to a depth of approximately $31.0 \mu \mathrm{m}$ and inserted between zirconia particles (Figs. $2 \mathrm{e}, \mathrm{f})$. No delamination and crack was observed between spots and zirconia substrate.

After hydrothermal treatment, the spots on zirconia turned into the rod-like crystals and had a shape of thin pin. The further magnified SEM image showed it was hexagonal and grew lengthwise which was similar as 


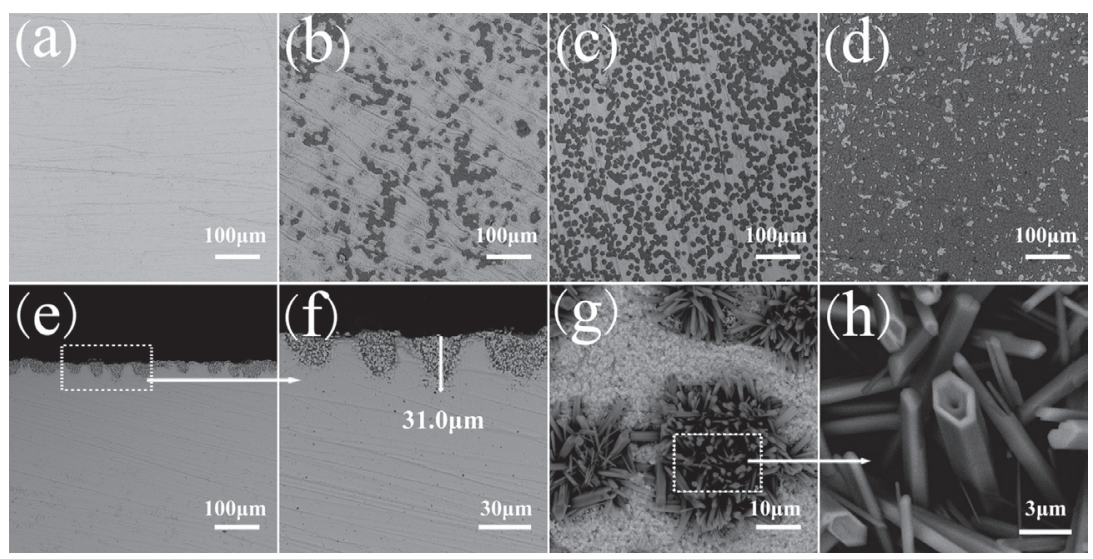

Fig. 2 Representative SEM images of zirconia surface after sintering.

(a) control group C, (b) group E1, (c) group E2, (d) group E3, (e) the vertical section of group E2 (500)), (f) the vertical section of group E2 $(2,000 \times)$, (g) group E2 after hydrothermal treatment, (h) magnification of crystallized rods.

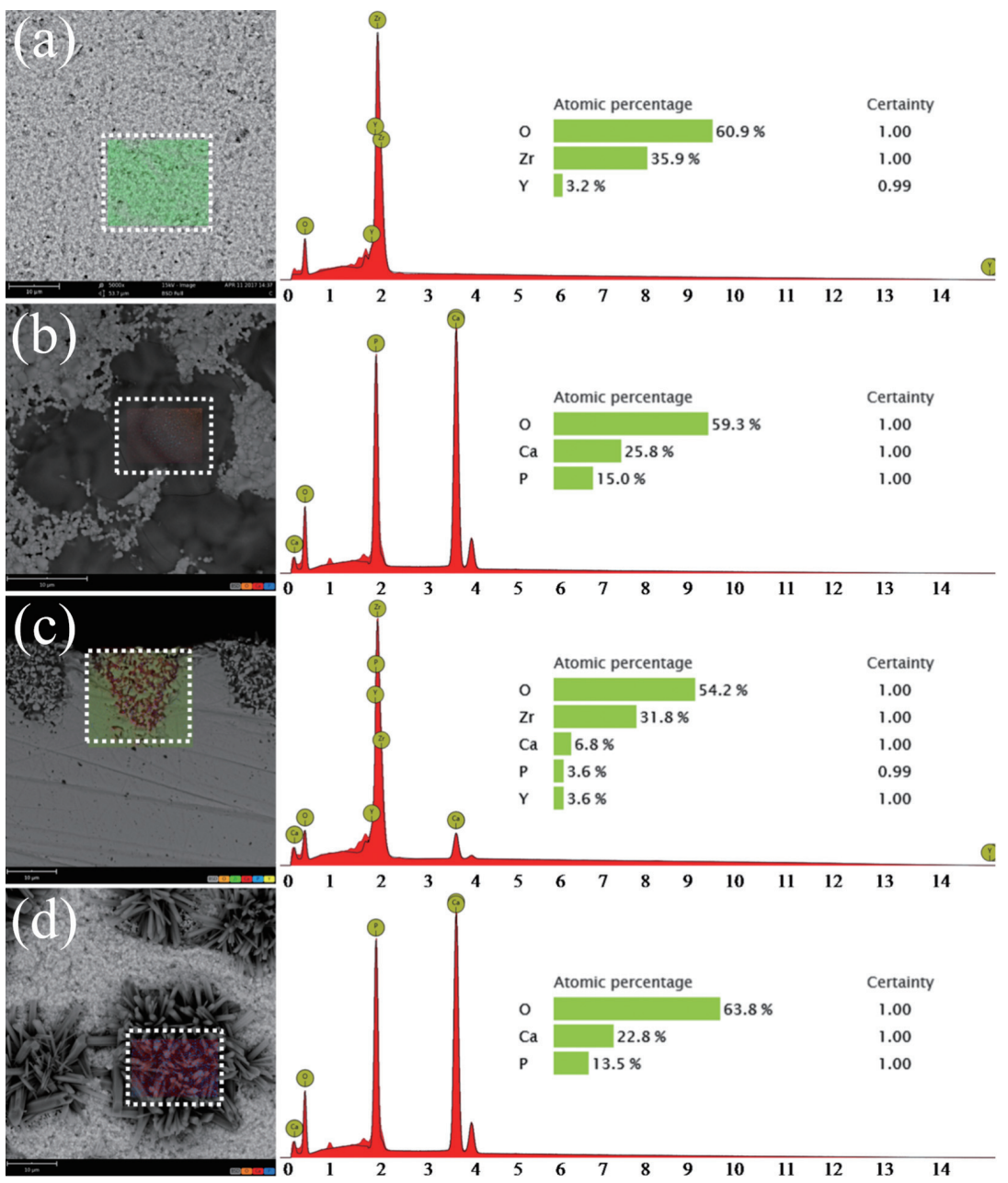

Fig. 3 EDS analysis of the zirconia surface.

(a) Control group C, (b) the spots of group E2 before hydrothermal treatment, (c) the vertical section of group E2, (d) cluster of group E2 after hydrothermal treatment. 
the characteristic of HAP (Figs. $2 \mathrm{~g}, \mathrm{~h}$ ).

EDS showed only $\mathrm{Zr}$, $\mathrm{O}$ and $\mathrm{Y}$ were detected in group $\mathrm{C}$ (Fig. 3a). The elemental composition of spots on modified zirconia revealed the existence of $\mathrm{O}, \mathrm{Ca}$ and $\mathrm{P}$ where the atomic percentages of $\mathrm{Ca}$ and $\mathrm{P}$ were 25.8 and $15 \%$, respectively (Fig. $3 \mathrm{~b}$ ). Besides, the section of the spots area showed the existence of $\mathrm{O}, \mathrm{Ca}$ and $\mathrm{P}$ where the atomic percentages of $\mathrm{Ca}$ and $\mathrm{P}$ were 6.8 and $3.6 \%$, respectively (Fig. 3c). After hydrothermal treatment, the EDS analysis of rod-like crystals confirmed the existence of $\mathrm{O}, \mathrm{Ca}$ and $\mathrm{P}$. The atomic percentages of $\mathrm{Ca}$ and $\mathrm{P}$ were 22.8 and $13.5 \%$, respectively (Fig. 3d).

$\mathrm{XRD}$ analysis showed that only diffraction peaks of $\mathrm{ZrO}_{2}$ was detected in group $\mathrm{C}$ and group E2 before hydrothermal treatment (Fig. 4a, b). After hydrothermal

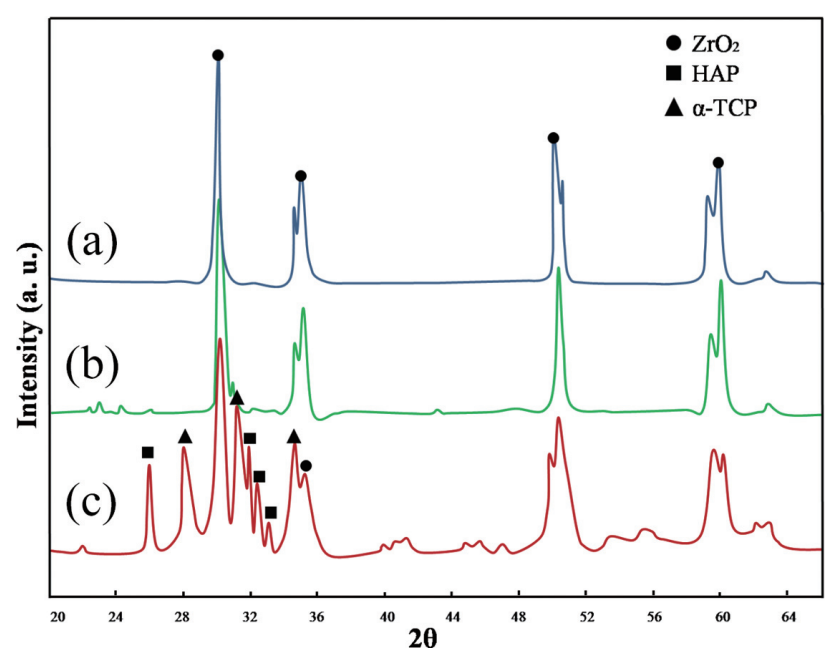

Fig. 4 XRD patterns of the zirconia surface.

(a) Control group C, (b) group E2 before hydrothermal treatment, (c) group E2 after hydrothermal treatment. treatment, diffraction peaks of alpha-tricalcium phosphate $(\alpha-\mathrm{TCP})$ and HAP were detected in group E2 (Fig. 4c).

\section{Dissolution behavior}

During the first 4 days, the ionic concentration of $\mathrm{Ca}^{2+}$ and $\mathrm{PO}_{4}{ }^{3-}$ increased rapidly and followed by a gradual increase on the following days. Ca-P modified zirconia before hydrothermal treatment showed the higher $\mathrm{Ca}^{2+}$ and $\mathrm{PO}_{4}{ }^{3-}$ release than that of after hydrothermal treatment and control group $(p<0.05)$, while no released $\mathrm{Ca}^{2+}$ and $\mathrm{PO}_{4}{ }^{3-}$ was tested in control group (Fig. 5).

\section{Three-point bending strength}

In Fig. 6, the three-point bending strengths were $\mathrm{C}=710.16 \pm 70.84 \quad \mathrm{MPa}, \quad \mathrm{E} 1=700.32 \pm 71.82 \quad \mathrm{MPa}$, $\mathrm{E} 2=689.23 \pm 65.79 \mathrm{MPa}$ and $\mathrm{E} 3=682.13 \pm 52.68 \mathrm{MPa}$, there was no statistically significant difference among these groups $(p>0.05)$.

\section{Osteoblast-like cellular responses}

The in vitro cellular responses to the Ca-P modified zirconia were observed in terms of cell morphology, proliferation, and functional activities using osteoblastlike MC3T3-E1 mouse pre-osteoblasts cells. Group C was tested for comparison purpose.

\section{Cell morphology}

At $24 \mathrm{~h}$ of cultivation, in group $\mathrm{C}$, the cells had 1 nuclei (in blue) which were round or oval, and actin filament (in red) exhibited spindle cytoskeletal appearance (Fig. 7a). While in E2 group, the cells had 1 or 3 nuclei and the actin filament gradually extended a polygon (Fig. $7 \mathrm{~b})$. At $72 \mathrm{~h}$ of cultivation, the number of cells and actin filament of the two groups increased obviously. Compared with the control group (Fig. 7c), more cells appeared on the group E2. Cells arrayed more intensive, showed a smaller gap between cells and the actin filament of cells in peripheral appeared more and longer
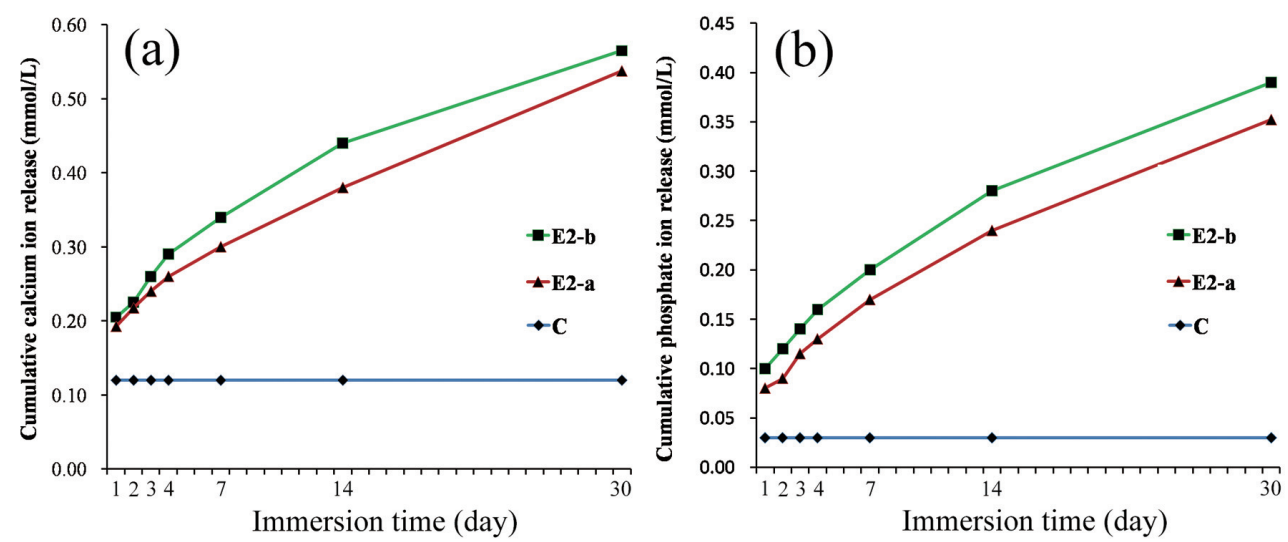

Fig. 5 Dissolution behavior of group C, group E2 before and after hydrothermal treatment. (a) Cumulative release of calcium ion with the time of immersion, (b) cumulative release of phosphoru ion with the time of immersion. 
at the same time point (Fig. 7d).

\section{Cell proliferation}

The cells on all zirconia proliferated actively with culture period, showing good cell viability. Overall, the cell proliferation of two groups gradually increased from day 1 up to days 7 , and the cells continued proliferating even up to 7 days (Fig. 8a). The resuts showed that the cell proliferation of group E2 was higher than that of group $\mathrm{C}$ at 1, 3, 5 and 7 days, respectively. No

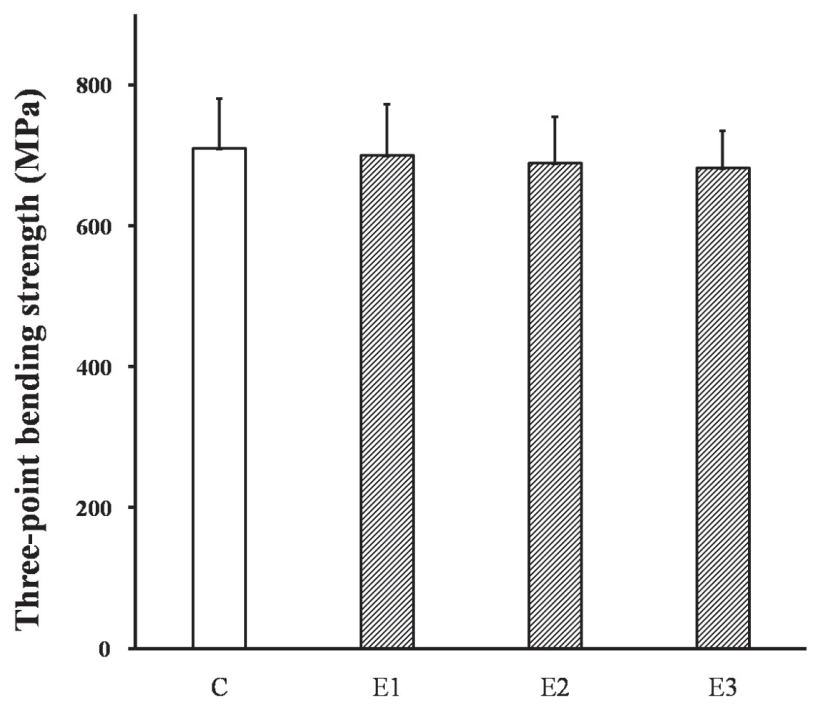

Fig. 6 Three-point bending strength of groups before hydrothermal treatment.

Bar represents mean \pm standard deviation $(n=10)$. There was no significant difference among groups $(p>0.05)$.

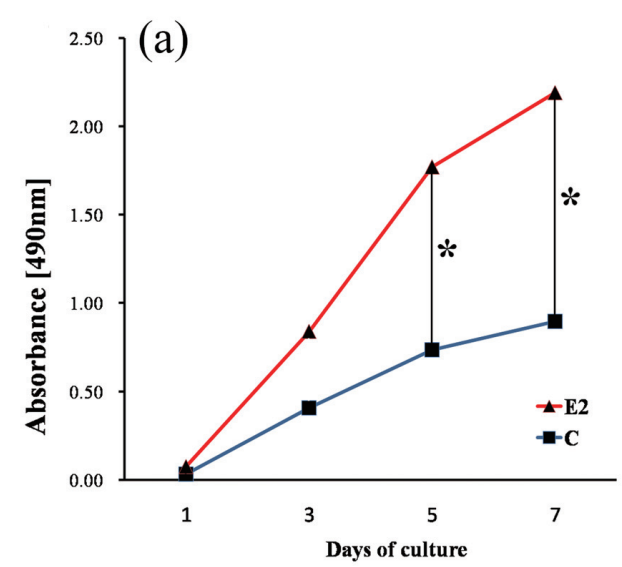

statistical differences were seen between the group E2 and control group at day 1 and days $3(p>0.05)$, while cell proliferation on group E2 induced significant increase at 5 and 7 days $(p<0.05)$. Specifically, the proliferation of cells cultured on E2 statistically improved from $0.041 \pm 0.014$ (at day 1) to $1.293 \pm 0.139$ (at days 7) $(p<0.05)$. The results indicated the Ca-P modified zirconia can promote osteoblast proliferation at long term, the difference was statistically significant.

\section{Cell differentiation}

The ALP activity of two groups increased from

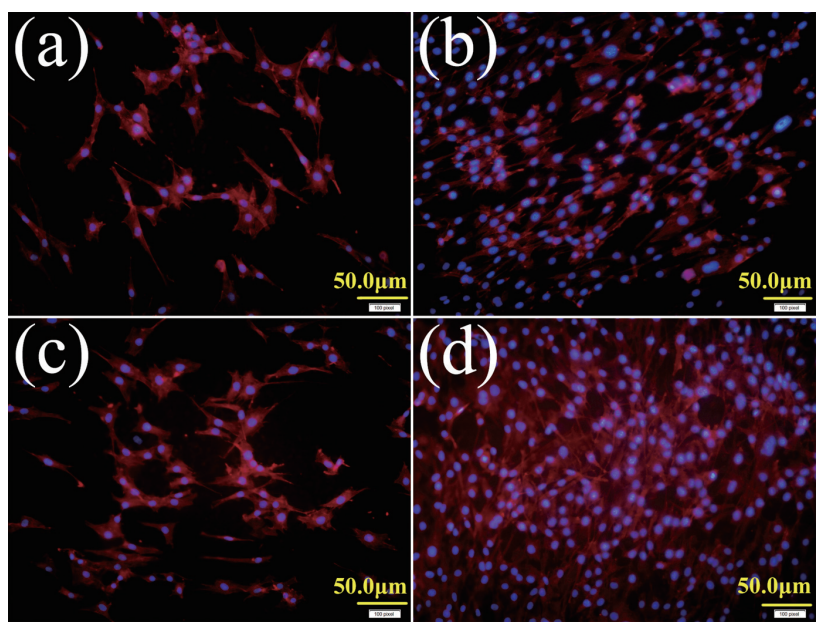

Fig. 7 DAPI fluorescence staining of MC3T3-E1 cells. Cells were fixed and stained with DAPI for nuclei (blue fluorescence), Phalloidin for actin filaments (red fluorescence). (a) and (c): cells adhered on group $\mathrm{C}$ for 24 and $72 \mathrm{~h}$, (b) and (d): cells adhered on group E2 for 24 and $72 \mathrm{~h}$, respectively.

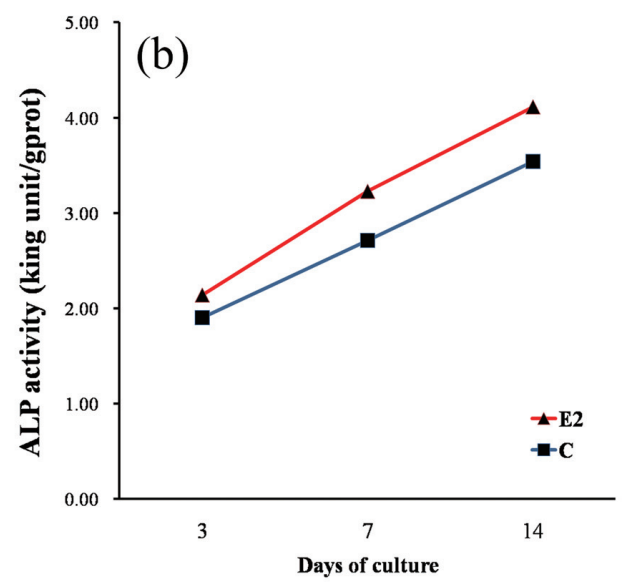

Fig. 8 (a) Cell proliferation kinetic of MC3T3-E1 cells on group C and E2 at 1, 3, 5 and 7 days $(*: p<0.05)$. (b) Alkaline phosphatase (ALP) activity of MC3T3-E1 cells on group C and E2 at 3, 7 and 14 days. There was no significant difference between group C and E2 within tested period $(p>0.05)$. 
initiation of differentiation until 14 days. At days 3, 7 and 14, the cells in group E2 exhibited lightly higher ALP activity as compared to that of group C. There was no statistically significance between group E2 and group C $(p<0.05)$ (Fig. 8b).

\section{DISCUSSION}

Zirconia is currently under investigation as a metalfree and white alternative to titanium implants ${ }^{26)}$. However, zirconia ceramics have low bone inductive and it is difficult to form a good osseointegration with bone tissue. Considerable efforts have been exerted to modify zirconia surface physically and chemically in order to provide the implant system enhanced cellular responses and tissue-implant osseointegration. Yet the ideal bone implant binding rates have not been achieved.

In this study, in order to simulate the composition of natural bone and tooth, $\mathrm{CaCl}_{2}$ and $\mathrm{NaH}_{2} \mathrm{PO}_{4} \cdot 2 \mathrm{H}_{2} \mathrm{O}$ were used as $\mathrm{Ca}$ source and $\mathrm{P}$ source, and $\mathrm{Ca} / \mathrm{P}$ ratio was controlled at 1.7. The liquid precursor infiltration method made the calcium and phosphorus infiltrated into zirconia by using the characteristics of high porosity of pre-sintered zirconia. Free $\mathrm{Ca}^{2+}$ and $\mathrm{PO}_{4}{ }^{3-}$ coated the zirconia surface and entered into the spaces between the zirconia particles during the immersion process. After dense sintering at $1,450^{\circ} \mathrm{C}, \mathrm{Ca}-\mathrm{P}$ compounds deposited on the zirconia surface changed into spots distribution (Figs. 2b, c, d) (The mechanism was shown in Fig. 9). Cracks were not observed due to the cluster formation. Cracks occurred on the coatings surface would indirect affect long-term effects of implants ${ }^{27)}$. Ca-P spots formation would avoid the crack occurring for its cluster-structure. Researchers focus on the fabrication of bioactive coatings on zirconia surface ${ }^{19-21)}$, however, the coatings could not combine with substrates well due to their different physicochemical properties, such as mismatched thermal expansion coefficients ${ }^{28)}$. In this study, Ca-P spots anchored with the zirconia (Figs. 2e, f). The calcium and phosphorus were firmly stuck in zirconia because of the zirconia shrinkage after sintering, which could avoid peeling-off from the zirconia surface effectively. Furthermore, the distribution densities of spots increased with the extension of immersion time indicated the distribution of Ca-P spots on zirconia could be controlled by adjusting the immersion time and times.

Three-point bending strength gradually decreased with the immersion time increasing. This was mainly because the structure of zirconia surface layer may be partially changed by the calcium and phosphorus infiltration. With immersion time increasing, more calcium and phosphorus would infiltrate into the zirconia, three-point bending strength would be influenced. However, there was no significant difference $(p>0.05)$ in three-point bending strength between Ca-P modified zirconia and control group. It indicated that this liquid precursor infiltration treatment had little effect on the mechanical strength of zirconia substrates.

Before hydrothermal treatment, the EDS analysis confirmed the main elements of the spots were $\mathrm{O}, \mathrm{Ca}$ and $\mathrm{P}$, and the stoichiometric $\mathrm{Ca} / \mathrm{P}$ mole ratio was approximately 1.67 (Fig. 3b). XRD results showed only diffraction peaks of $\mathrm{ZrO}_{2}$ were detected and no other obvious diffraction peaks of new phase were observed (Fig. 4a, b). It indicated the spots were amorphous calcium phosphate (ACP) compounds. After hydrothermal treatment, the amorphous calcium phosphorus on zirconia turned into rod-like crystals (Fig. 2h) whose structure was very analogous to that of HAP and the stoichiometric $\mathrm{Ca} / \mathrm{P}$ mole ratio was approximately 1.67 . XRD confirmed the diffraction peaks of $\alpha$-TCP and HAP (Fig. 4c). This was because the ACP on the zirconia ceramics regains the hydroxyl in the hydrothermal treatment, which was similar to the research of $\mathrm{Ha}^{29)}$. On the other hand, it confirmed the ACP is a precursor to the formation of HAP, which is the final, stable product in the precipitation of the calcium and phosphate ions from neutral or basic solutions ${ }^{30)}$.

The chemical composition and structure determine their biocompatibility and biological activity. Hahn et al. demonstrated that the HAP had excellent biological

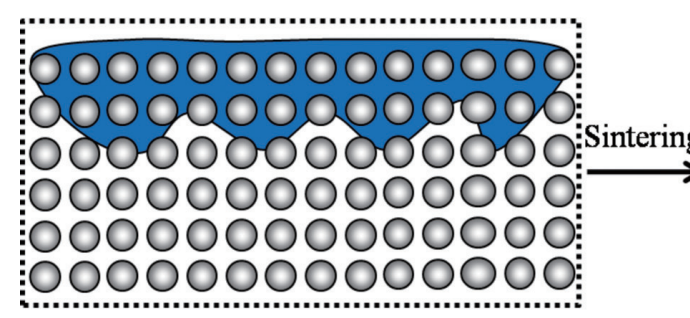

A

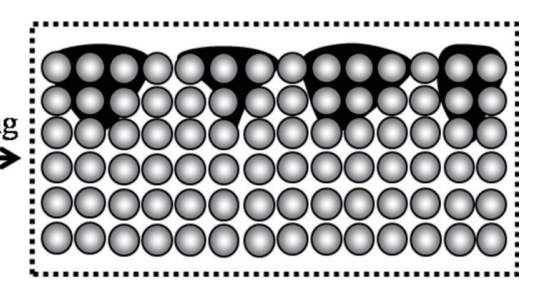

B

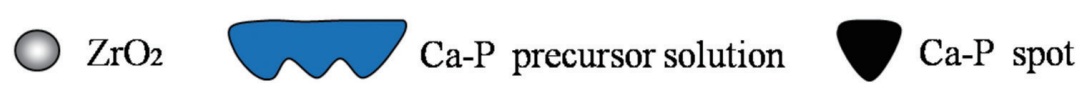

Fig. 9 The mechanism of Ca-P precursor modified zirconia.

A: pre-sintered zirconia was immersed in the Ca-P precursor solution, B: Ca-P spots formed on zirconia after sintering. 
cellular responses in vitro, as well as enhanced bioactivity, due to their high degree of crystallinity ${ }^{31)}$. $\mathrm{Hu}$ et al. suggested cells are more likely to adsorbe and proliferate on a well-crystallized HAP coating than on an amorphous HAP coating ${ }^{32}$. However, it is generally known that bone apatite is poorly crystalline and nonstoichiometric due to the presence of other ions such as magnesium and carbonate ions ${ }^{33)}$. Besides, studies showed that the rate of new bone formation coincides more closely with the resorption rate of poorly crystalline or ACP ceramics ${ }^{34,35)}$. Therefore, reducing crystallinity of calcium phosphate based materials may promote osteoblast adhesion and function ${ }^{36)}$. With these considered, in this report, the zirconia surface was modified with ACP.

In this study, the MC3T3-E1 cells behaved differently responding to the Ca-P modified zirconia compared to control group. As Fig. 7b showed, $24 \mathrm{~h}$ later, the cells adhered properly and spread better in group E2, cells were observed as de-bulked and elongated cytoskeleton and the number of cells was increased than that of control group. Seventy two hours later, more cells of fusiform and polygon began to adhere and stretch out the more parapodium in group E2 (Fig. 7d), the number of cells was increased as well. Cells showed well-organized actin fibers and a much flatter appearance than control group. This is only to be expected, because the main mineral component of bone is a complex inorganic calcium phosphate system called apatite ${ }^{37}$. It has been suggested that cell morphology with a fully spreading shape and a regular cytoskeleton enables better cell proliferation and differentiation ${ }^{38)}$. Figure 8 a showed there was no statistically significance on proliferation before 3 days between group E2 and group C. After day 5, group E2 had significantly higher $(p<0.05)$ cell proliferation. The result indicated that the $\mathrm{Ca}-\mathrm{P}$ modified zirconia could enhance the proliferation of osteoblast-like cells. There was no stastitically significance of ALP activity between group E2 and group C $(p<0.05)$ which meaned the Ca-P modified zirconia may not stimulate the differentiation of cells. On the other hand, surface roughness was reported to be beneficial for the formation of more rigid bonds with host tissues ${ }^{39)}$. The Ca-P spots formed on zirconia increased the surface roughness and the specific surface area. Osteoblast-like cells tend to attach to rougher surfaces, which is the opposite of the behavior of epithelial cells and fibroblasts ${ }^{40)}$, which would be more favorable for bone remodeling.

On the other hand, ACP-containing bioactive materials stimulate mineral growth by increasing the calcium and phosphate concentrations within the lesion, especially in acidic environment, thereby shifting the thermodynamic driving forces of the solution toward the formation of apatite ${ }^{30}$. As the dissolution experiments results showed, Ca-P spots modified zirconia exhibited the higher $\mathrm{Ca}^{2+}$ and $\mathrm{PO}_{4}{ }^{3-}$ release before hydrothermal treatment compared to after hydrothermal treatment $(p<0.05)$. While Ca-P spots were inserted with zirconia, more calcium and phosphate would be stuck in the zirconia, which would long-term release and improve the bioactivity of zirconia. In addition, there was no largescale delamination or coating peel off which proved the stability of the Ca-P spots after immersion in deionized water. ACP has shown anti-cariogenic properties with remineralization potential ${ }^{41)}$. Moreover, calcium and phosphorus ions are the substances contained in the mitochondria of osteoblasts, and calcium ion itself is the second messenger of cells, which may become one of the induction signals of cells. Thus, the good bone biocompatibility of these materials makes them suitable for the repair damaged or diseased bone. Further studies on the effect of Ca-P modified zirconia contribution on the biocompatible are still being conducted.

Furthermore, liquid precursor infiltration boasts the potential of wider application for other materials. It possesses the unique advantages in achieving minor content doping with high homogeneity, surface modification, gradient and functional materials and having no restrictions regarding substrate shape, which could serve as a promising technology in the future.

\section{CONCLUSIONS}

Ca-P liquid precursor infiltration is a simple and effective method to modify the zirconia ceramic surface. Ca-P spots could anchored with zirconia closely and have no significant effect on the mechanical strength of zirconia. Importantly, Ca-P modified zirconia could effectively enhance the cell attachment and proliferation of osteoblast-like cell.

\section{ACKNOWLEDGMENTS}

This work was supported by the Beijing Natural Science Foundation [Grant No. 7152065] and the National Natural Science Foundation of China [Grant No. 81371175, 81671027].

\section{CONFLICT OF INTEREST}

The authors declare that they have no conflict of interest.

\section{REFERENCES}

1) Brånemark PI, Hansson BO, Adell R, Breine U, Lindström J, Hallén O, Ohman A. Osseointegrated implants in the treatment of the edentulous jaw. Experience from a 10-year period. Scand J Plast Reconstr Surg Hand Surg Suppl 1977; 16: $1-132$.

2) Osman R, Swain M. A critical review of dental implant materials with an emphasis on titanium versus zirconia. Materials 2015; 8: 932-958.

3) Takemoto S, Tasaka A, Hattori M, Sakurai K, Oda Y. Discoloration of Ti-20Cr alloy in oral environment and its surface characterization. Dent Mater J 2012; 31: 1060-1067.

4) Javed F, Al-Hezaimi K, Almas K, Romanos GE. Is titanium sensitivity associated with allergic reactions in patients with dental implants? A systematic review. Clin Implant Dent Relat Res 2013; 15: 47-52.

5) Sennerby L, Dasmah A, Larsson B and Iverhed M. Bone tissue responses to surface-modified zirconia implants: A 
histomorphometric and removal torque study in the rabbit. Clin Implant Dent Relat Res 2005; 7 Suppl1: s13-20.

6) Subramani K, Wismeijer D. Decontamination of titanium implant surface and re-osseointegration to treat periimplantitis: a literature review. Int $\mathrm{J}$ Oral Maxillofac Implants 2012; 27: 1043-1054.

7) Kumar R, Lerski R A, Gandy S, Clift BA, Abboud RJ. Safety of orthopedic implants in magnetic resonance imaging: an experimental verification. J Orthop Res 2006; 24: 1799-1802.

8) Lundberg K, Wu L, Papia E. The effect of grinding and/or airborne-particle abrasion on the bond strength between zirconia and veneering porcelain: a systematic review. Acta Biomater Odontol Scand 2017; 3: 8-20.

9) Christel P, Meunier A, Dorlot JM, Crolet JM, Witvoet J, Sedel L, Boutin P. Biomechanical compatibility and design of ceramic implants for orthopedic surgery. Ann N Y Acad Sci 1988; 523: 234-256.

10) Oguri T, Tamaki Y, Hotta Y, Miyazaki T. Effects of a convenient silica-coating treatment on shear bond strengths of porcelain veneers on zirconia-based ceramics. Dent Mater J 2012; 31: 788-796.

11) Han JM, Hong G, Matsui H, Shimizu Y, Zheng G, Lin H, Keiichi S. The surface characterization and bioactivity of NANOZR in vitro. Dent Mater J 2014; 33: 210-219.

12) Marti A. Inert bioceramics $\left(\mathrm{Al}_{2} \mathrm{O}_{3}, \mathrm{ZrO}_{2}\right)$ for medical application. Injury 2000; 31 (Suppl 4): 33-36.

13) Akagawa $Y$, Ichikawa $Y$, Nikai H, Tsuru H. Interface histology of unloaded and early loaded partially stabilized zirconia endosseous implant in initial bone healing. J Prosthet Dent 1993; 69: 599-604.

14) He M, Zhang Z, Zheng D, Ding N, Liu Y. Effect of sandblasting on surface roughness of zirconia-based ceramics and shear bond strength of veneering porcelain. Dent Mater J 2014; 33 : 778-785.

15) Hoffmann O, Angelov N, Zafiropoulos GG, Andreana S. Osseointegration of zirconia implants with different surface characteristics: an evaluation in rabbits. Int J Oral Maxillofac Implants 2012; 27: 352-358.

16) Kakura K, Yasuno K, Taniguchi Y. Zirconia implant with rough surface produced by YAG laser treatment: Evaluation of histomorphology and strength of osseointegration. J Hard Tissue Biol 2014; 23: 77-82.

17) Gao L, Guo H, Wei L, Xu H. Microstructure and mechanical properties of yttria stabilized zirconia coatings prepared by plasma spray physical vapor deposition. Ceram Int 2015; 41: 8305-8311.

18) Bangi UKH, Park CS, Baek S, Park HH. Sol-gel synthesis of high surface area nanostructured zirconia powder by surface chemical modification. Powder Technol 2013; 239: 314-318.

19) Pelaez-Vargas A, Gallego-Perez D, Magallanes-Perdomo M, Fernandes MH, Hansford DJ, De Aza AH, Pena P, Monteiro FJ. Isotropic micropatterned silica coatings on zirconia induce guided cell growth for dental implants. Dent Mater 2011; 27: 581-589.

20) Kaneko H, Sasaki H, Honma S, Hayakawa T, Sato M, Yajima $\mathrm{Y}$, Yoshinari M. Influence of thin carbonate-containing apatite coating with molecular precursor method to zirconia on osteoblast-like cell response. Dent Mater 2014; 33: 39-47.

21) Han SH, Kim KH, Han JS, Koo KT, Kim T, Seol YJ, Lee YM, $\mathrm{Ku}$ Y, Rhyu IC. Response of osteoblast-like cells cultured on zirconia to bone morphogenetic protein-2. J Periodontal Implant Sci 2011; 41: 227-233.

22) Subaşı MG, Özgür İnan. Evaluation of the topographical surface changes and roughness of zirconia after different surface treatments. Lasers Med Sci 2012; 27: 735-742.

23) Kitsugi T, Yamamuro T, Takeuchi H, Ono M. Bonding behavior of three types of hydroxyapatite with different sintering temperatures implanted in bone. Clin Orthop Relat Res 1988; 234: 280-290.
24) Fosca M, Komlev VS, Fedotov AY, Caminiti R, Rau JV. Structural study of octacalcium phosphate bone cement conversion in vitro. ACS Appl Mater Interfaces 2012; 4: 62026210.

25) Liu GW, Xie ZP, Yin WU. Research progress of manipulating composition and properties of ceramics via liquid precursor infiltration technique. J Inorg Mater 2011; 26: 1121-1128.

26) Kohal RJ, Baechle M, Han JS, Hueren D, Huebner U and Butz F. In vitro, reaction of human osteoblasts on aluminatoughened zirconia. Clin Oral Implants Res 2009; 20: 12651271.

27) Stefanic M, Krnel K, Pribosic I, Kosmac T. Rapid biomimetic deposition of octacalcium phosphate coatings on zirconia ceramics (Y-TZP) for dental implant applications. Appl Surf Sci 2012; 258: 4649-4656.

28) Girolamo GD, Blasi C, Schioppa M, Tapfer L. Structure and thermal properties of heat treated plasma sprayed ceriayttria co-stabilized zirconia coatings. Ceram Int 2010; 36: 961-968.

29) $\mathrm{Ha}$ JS. Hydrothermal Coating of hydroxyapatite on $\mathrm{ZrO}_{2}$ ceramics. J Korean Ceram 2006; 43: 463-468.

30) Zawaideh FI, Owais AI, Kawaja W. Ability of pit and fissure sealant-containing amorphous calcium phosphate to inhibit enamel demineralization. Int J Clin Pediatr Dent 2016; 9: 1014.

31) Hahn BD, Lee JM, Park DS, Choi JJ, Ryu J, Yoon WH, Choi JH, Lee BK, Kim JW, Kim HE, Kim SG. Enhanced bioactivity and biocompatibility of nanostructured hydroxyapatite coating by hydrothermal annealing. Thin Solid Films 2011; 519: 8085-8090.

32) Hu QH, Tan Z, Liu YK, Tao JH, Cai YR, Zhang M, Pan H, Xua X, Tang R. Effect of crystallinity of calcium phosphate nanoparticles on adhesion, proliferation, and differentiation of bone marrow mesenchymal stem cells. J Mater Chem 2007; 17:4690-4698.

33) Bigi A, Foresti E, Gregorini R, Ripamonti A, Roveri N, Shah JS. The role of magnesium on the structure of biological apatites. Calcif Tissue Int 1992; 50: 439-444.

34) Frayssinet P, Trouillet JL, Rouquet N, Azimus E, Autefage A. Osteointegration of macroporous calcium phosphate ceramics having a different chemical composition. Biomaterials 1993; 14: 423-429.

35) Klein CPAT, Driessen AA, de Groot K, van den Hoof A. Biodegradation behavior of various calcium phosphate materials in bone tissue. J Biomed Mater Res A 1983; 17: 769-784.

36) Balasundaram G, Sato M, Webster TJ. Using hydroxyapatite nanoparticles and decreased crystallinity to promote osteoblast adhesion similar to functionalizing with RGD. Biomaterials 2006; 27: 2798-2805.

37) Ambrosio AM, Sahota JS, Khan Y, Laurencin CT. A novel amorphous calcium phosphate polymer ceramic for bone repair: I. Synthesis and characterization. J Biomed Mater Res 2001; 58: 295-301.

38) He J, Zhou W, Zhou X, Zhong X, Zhang X, Wan P, Zhu B, Chen W. The anatase phase of nanotopography titania plays an important role on os teoblast cell morphology and proliferation. J Mater Sci Mater Med 2008; 19: 3465-3472.

39) Lew KS, Othman R, Ishikawa K, Yeoh FY. Macroporous bioceramics: a remarkable material for bone regeneration. $J$ Biomater Appl 2012; 27: 345-358.

40) Boyan BD, Hummert TW, Dean DD, Schwartz Z. Role of material surfaces in regulating bone and cartilage cell response. Biomaterials 1996; 17: 137-146.

41) Silva KG, Pedrini D, Delbem AC, Ferreira L, Cannon M. In situ evaluation of the remineralizing capacity of pit and fissure sealants containing amorphous calcium phosphate and/or fluoride. Acta Odontol Scand 2010; 68: 11-18. 